\title{
Normal Lipase Pancreatitis: A Case Report
}

\author{
Bouaiyda Ayoub*1, Chouikh $\mathrm{C}^{1}$, Ababou $\mathbf{M}^{1}$, Jeddab A ${ }^{1}$, Zidouh $\mathrm{S}^{2}$, Belyamani $\mathrm{L}^{2}$ \\ ${ }^{1}$ Department of Anesthesiology and Intensive Care, Military Hospital Mohammed V, Faculty of Medicine and Pharmacy of Rabat, Mohammed V \\ University, Rabat, Morocco.
}

${ }^{2}$ Emergency Department, Military Hospital Mohammed V, Faculty of Medicine and Pharmacy of Rabat, Mohammed V University, Rabat, Morocco.

*Corresponding Author: Bouaiyda Ayoub, Department of Anesthesiology and Intensive Care, Military Hospital Mohammed V, Faculty of Medicine and Pharmacy of Rabat, Mohammed V University, Rabat, Morocco.

\section{Received Date: December 082021 | Accepted Date: January 252022 | Published Date: January 31, 2022}

Citation: B Ayoub, C Chouikh, M Ababou, A Jeddab, S Zidouh, et al. (2022). Normal Lipase Pancreatitis: A Case Report. International Journal of Clinical Case Reports and Reviews. 10(4); DOI: 10.31579/2690-4861/195

Copyright: (c) 2022 Bouaiyda Ayoub, This is an open-access article distributed under the terms of the Creative Commons Attribution License, which permits unrestricted use, distribution, and reproduction in any medium, provided the original author and source are credited.

\begin{abstract}
:
Acute pancreatitis is a serious and potentially fatal condition, caused by the pancreas self-digesting with its own accidentally activated enzymes. its diagnosis is based on a combination of clinical, biological and radiological evidence.

The absence of lipase elevation during acute pancreatitis is extremely rare and can sometimes make the diagnosis difficult and therefore delay the treatment.

We will report the case of a 27 -year-old female patient, with no previous history of the disease, who consulted us for acute abdominal pain, and whose diagnosis, after an etiological investigation, was pancreatitis with normal lipase levels.
\end{abstract}

Key words: pancreatitis; lipase; abdominal pain

\section{Introduction:}

Acute pancreatitis is an autodigestion of the pancreas by its own accidentally activated enzymes. It is accompanied by an increase in the serum level of pancreatic enzymes, specifically lipase. It has an annual incidence of 40 cases/year per 100,000 adults, with a mortality rate of 5\% which can increase with age and multivisceral dysfunction to $47 \%$ [1].

The diagnosis is based on clinical, biological and radiological criteria and is a frequent pathology in emergencies. The most frequent causes are alcohol, vesicular lithiasis, hypertriglyceridaemia, hypercalcaemia, endoscopic retrograde cholangiopancreatography and trauma. But it can also be idiopathic in $20 \%$ of cases [2]. We're here to report the case of a 27 years old woman, who presented to the emergency department with acute abdominal pain and was later diagnosed with pancreatitis with normal lipase.

\section{Case presentation:}

The case involved a 27 -year-old female patient with no previous history who consulted the emergency room at $\mathrm{H} 2$ of the onset of symptoms for intense epigastralgia, of abrupt onset, transfixing with posterior irradiation, calmed by anteflexion accompanied by vomiting, without transit disorders.
The clinical examination showed a patient in good general condition, temperature at $37^{\circ} \mathrm{c}$, tachycardia at $94 \mathrm{bpm}$, normal blood pressure $120 / 70$ $\mathrm{mmHg}, \mathrm{SpO} 2$ at $99 \%$ on ambient air, capillary blood sugar at $1.14 \mathrm{~g} / \mathrm{l}$ and exaggeration of the pain by palpation of the epigastrium. The rest of the examination was unremarkable. In view of the typical clinical picture, a lipase was requested and found to be normal (20 IU). The patient was then put on symptomatic treatment based on a proton pump inhibitor and antiemetic.

Two days later, the patient was admitted to the emergency room and then to the observation room for investigation. The blood count showed a normal white blood cell count of 8700 cells $/ \mathrm{mm} 3$, lipase was still normal (32 IU). Liver function tests were undisturbed, ASAT (30IU), ALAT (28IU), GGT (20IU), PAL (32IU) and CRP (66mg/l). Given the typical symptomatology and its persistence after 48 hours, an injected abdominal CT scan was ordered which showed a swollen pancreas lacking its normal lobulations which corresponds to a Balthazar stage B, a slight dilatation of the intra- and extra-hepatic bile ducts with a thin-walled distended gallbladder and a stone [Figure 1]. The diagnosis of pancreatitis with normal lipase was thus retained, the patient was initially given a filling, analgesic treatment, with temporary cessation of oral feeding as long as she could not tolerate it, then she was transferred to the gastroenterology department for further management. 


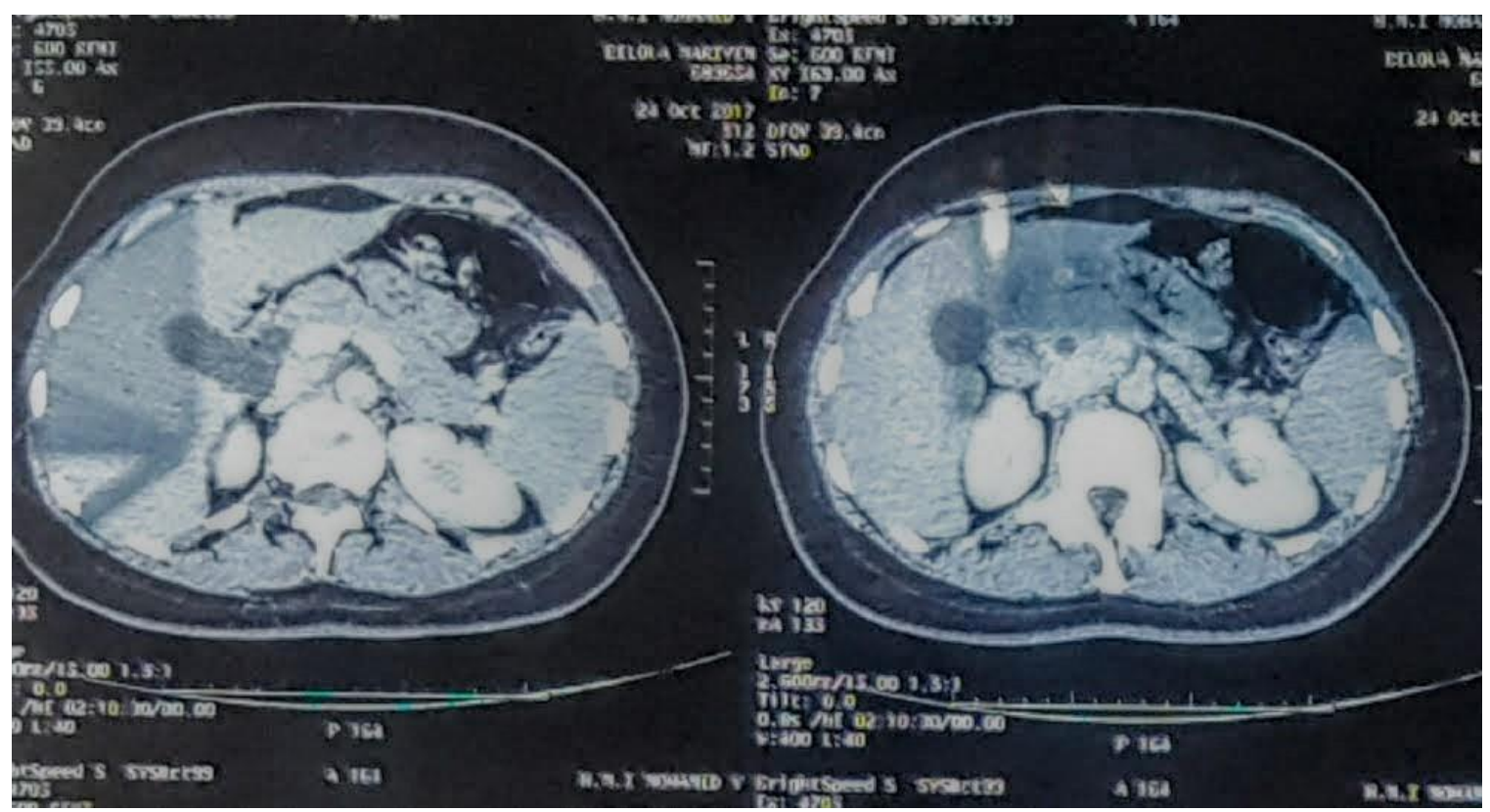

Figure 1: A C+ abdominal CT scan showing a swollen pancreas that has lost its normal lobulations, with a thin-walled distended gallbladder with a stone.

\section{Discussion:}

According to the Atlanta 2012 conference, the diagnosis of acute pancreatitis is based on the presence of 2 of the following 3 criteria: suggestive abdominal pain (epigastric with dorsal radiation), a serum plasma lipase (or plasma amylase) level greater than 3 times normal, and a characteristic abnormality on imaging (CT, MRI or ultrasound). Imaging is not useful for diagnosis if the first two criteria are present on admission, it will only be performed if one of the two criteria is absent or if the patient has visceral failure [3].

Plasma lipase is one of the mainstays of the diagnosis. It is a $48 \mathrm{kD}$ enzyme involved in digestion and secreted by the exocrine pancreas, and participates with gastric lipase and intestinal lipase in the hydrolysis of long-chain triacylglycerols supplied by the diet. The pancreatic enzyme secreted in its active form is by far the most important enzyme in fat digestion. It should be noted that several elements work together to ensure that the pancreatic cells are effectively protected from enzymatic digestion: Enzymes are secreted as inactive zymogens. The activating enzyme, trypsin, is released from the trypsinogen in the intestine and not in the pancreatic ducts and the secretory trypsin inhibitor is able to sequester much of the trypsin activity. There are small amounts of zymogens and possibly pancreatic enzymes in the plasma. The concentration of these enzymes increases dramatically during pancreatitis. It is the turn of the plasma protease inhibitors to come into play. These are a1-antitrypsin, a2-macroglobulin, inter-a1-trypsin inhibitor and a1-antichymotrypsin. These inhibitors are able to bind and inactivate pancreatic proteases [4].

During acute pancreatitis its level increases in the first 3 to 6 hours, peaking at 24 hours, then remains high for one to two weeks, with a halflife of 7 to 14 hours. It is produced by the acinar cells of the ductal system of the pancreas but also by the kidneys, so that renal injury can increase its level [5]. Nevertheless, a normal lipase level in acute pancreatitis is extremely rare, indeed recent studies have shown that the negative predictive value of lipase is $94 \%$ to $100 \%$ [6].

In the literature, several cases of pancreatitis with normal lipase have been described, two of which were diagnosed in circumstances identical to those of our patient [7]. In both patients lipase was measured on several occasions and always returned normal, the diagnosis was only made afterwards by imaging.

In our case the patient had only the typical pain on admission and since the patient presented to the emergency department with pain, the CT scan had no indication and so only the plasma lipase level was measured which came back normal (23IU). After 48 hours from the beginning of the symptoms, a second dosage was necessary and since it always came back normal (32UI), and in front of the typical symptomatology, a $\mathrm{C}+$ abdominal scan was performed and showed a pancreatitis classified as Balthazar stage B. Our patient had clinical and radiological criteria in favor of acute pancreatitis, which are, according to international recommendations, sufficient to make the diagnosis. And given the presence of a gallstone in the gallbladder and the distension of the intraand extra-hepatic bile ducts, we are rather oriented towards a lithiasis cause.

\section{Conclusion}

In conclusion, acute pancreatitis is a life-threatening emergency. Its diagnosis is based on 3 pillars: clinical, biological and radiological, but it is sometimes difficult to diagnose a normal lipase level,

The practitioner should always consider performing an imaging test in front of a suggestive clinical presentation.

\section{Acknowledgements}

$\mathrm{AB}, \mathrm{MA}$, and $\mathrm{AJ}$ examined the patient and drafted the manuscript. LB evaluated the findings and gave important clinical opinions. CC and SZ participated in the design of the case report and helped to draft the manuscript. All authors read and approved the final manuscript.

\section{Conflict of interest:}

The authors declare no competing interests

\section{References:}

1. Granger J, Remick D. (2005). Acute Pancreatitis: Models, Markers, and Mediators. Shock. 24:45-51. 
2. Shah AM, Eddi R, Kothari ST, Maksoud C, DiGiacomo WS, Baddoura W. (2010). Acute pancreatitis with normal serum lipase: a case series. JOP. 11(4):369-372.

3. Banks PA, Bollen TL, Dervenis C, Gooszen HG, Johnson CD, Sarr MG, et al. (2013). Classification of acute pancreatitis-2012: revision of the Atlanta classification and definitions by international consensus. Gut. 62(1):102-111.

4. Vaysse N. (2005). Physiologie du pancréas exocrine. EMCHépato-Gastroenterologie. 2(2):59-74.
5. Cartier T, Sogni P, Perruche F, Meyniard O, Claessens Y-E, Dhainaut J-F, et al. (2006). Normal lipase serum level in acute pancreatitis: a case report. Emerg Med J. 23(9):701-702.

6. Al-Bahrani AZ, Ammori BJ. (2005). Clinical laboratory assessment of acute pancreatitis. Clin Chim Acta. 362(1-2):2648.

7. Limon O, Sahin E, Kantar FU, Oray D, Ugurhan AA. (2016). A rare entity in ED: Normal lipase level in acute pancreatitis. Turkish Journal of Emergency Medicine. 16(1):32-34.
This work is licensed under Creative Commons Attribution 4.0 License
Ready to submit your research? Choose Auctores and benefit from:

$>$ fast, convenient online submission

$>$ rigorous peer review by experienced research in your field

$>$ rapid publication on acceptance

$>$ authors retain copyrights

$>$ unique DOI for all articles

$>$ immediate, unrestricted online access

At Auctores, research is always in progress.

Learn more https://auctoresonline.org/journals/international-journal-of-clinicalcase-reports-and-reviews 